\title{
Abd al-Razzāq Kāshānī: His Life, Works and Contribution to Sufism
}

\author{
Fatemeh Hashtroodi \\ University of Malaya, ztayefeh@yahoo.com
}

\begin{abstract}
Kāshāni is one of the most influential Sufi authors of later Islamic history. He wrote disseminated commentaries and important treatises, both in Arabic and Persian, which are rooted in Ibn al-'Arabī's ontological discourse. His works made him one of the great exponents and promoters of the School of Waḥdah al-Wujūd of Ibn 'Arabī after Șadr al-Dīn Qūnawī and advocates the intellectual discipline and School of Shaykh Akbar. His simple, scholarly manner used to explain and classify Ibn 'Arabī's teaching. His remarkable esoteric interpretation, Ta'wīlāt al-Qurān; although compatible with Ibn al-'Arabī's basic world view, there are important differences of perspective that mark Kāshānī as an independent thinker. His commentary on Fusūs al-Hikam, in which he discusses about the matter of Waḥdah al-Wujūd, promoted Ibn 'Arabī's teaching into the Persian speaking world.
\end{abstract}

Keywords: Abd al-Razzāq Kāshānī, Sufism

\section{Introduction}

Our knowledge about Kāshānī's life is very little. What we know about him is limited to sporadic information, written by him in some of his treatises, according to demands of text and not with the intention of introducing himself. In addition, there are few historian books from which we can derive information about him. The collection of Kāshān̄̄'s Treatises, by Majid Hādī Zādeh, however, should be mentioned, as it includes information about Kāshānī’s life. ${ }^{1}$ This paper depicts great interest in the prepration of Kāshān̄̄'s biography. In addition, it will present his works and his place in Sufism, especially his impact on Persian Sufism.

\section{The Life of Kāshānī}

Kamāl al-Dīn Abū al-Faḍl 'Abd al-Razzāq Ibn Jamāl al-Dīn Abū al-Ghanā'im al-Kāshānī (650/1252 to 736/1335) was born into a

\footnotetext{
1 Majīd Hādī Zādeh, Majmū 'at Rasā'il wa Muṣannafāt (Tehran: Mirāth Maktūb, 2000).
} 
Persian family in Kāshān, located in the province Khurāsān and 240 Kilometer south of Tehran. He, therefore, was sometimes called Qāshī, Qāsānī, Kāshī, which all are the different names of his birth place, Kāshān. ${ }^{2}$

The oldest source mentioned to Abd al-Razzāq Kāshānī is the summarization of Majma ' al-Ādāb fi Mu 'jam al-Alqā b, by Ibn alFūwațī (d. 624/1227), who died sixteen years before Kāshānī. ${ }^{3} I n$ addition, we can learn about Kāshānī in the writing of his disciple, Qayșarī Rūmī (d.751/1350), whose commentary on Fusūs alHikam is well known. He recognized the mane of Kāshānī's fathers as Abū al-Faḍl, with the tilte of kamāl al-Din, and, therefore, described his master as "perfection of nation, reality and religion" (Kamāl al-Millah Wa al-Haq Wa al-Dīn). ${ }^{5}$ This title is also confirmed by 'Allāmah Amīn 'Āmilī (d. 1284/1905)', Muhaddith Qumī (d. 1294/1915). ${ }^{7}$ Both Ibn al-Fūwațī and Qayṣā̄ identified the name of his grandfather as Abū al-Ghanā'im. ${ }^{8}$

2 Ibn al-Fūwațī al-Shayban̄i, Majma' al-Ādāb fì Mu'jam al-Alqāb, ed. Muhammad al-Kāẓim (Tehran: Irshād Islāmī, 1995), 4:180, no: 3620; Dawūd Ibn Mahmūd al-Qayșarī, Sharh Fuṣ̄us al-Hikam (Tehran: Elmī Farhangī, 1996), 4; Mudarris Tabrizī, Rayhāanah al-Adab (Tehran: Khayyām, 1995), 34; Pierre Lory, Les Commentoires esoteriques du Quran, Persian trans. Zaynab Pudineh Āqāì (Tehran: Hikmat, 2004), 25.

3 Kamāl al-Dīn 'Abd al-Razzāq Ibn Aḥmad Ibn al-Fūwațī was an Iraqi historian, who wrote a great deal, but whose works have mostly been lost. His most important work is Majma 'al-Ādāb fi Mu'jam al-Alqāab in 50 volumes, which is lost its large portions, but only two volumes ( $4 \& 5)$ are survied. They are in Library virtual Damascus and library of University of Lahore in Pakistan (For more information. See NK Singh, Encyclopaedic Historiography of Muslim World, 374).

4 Dāwūd Ibn Maḥmūd Ibn Muhammad Qayșarī was the disciple of 'Abd alRazzāq Kāshānī. His systematic philosophical introduction to Fuṣuṣ alHikam itself became the object of other commentaries. See Rama Sankar Yadav and B.v. Mandal, Global Encyclopedia of Education, ed. N. K. Singh, Global Vision Publishing Ho., 2007), 1:121).

5 Al-Qayșarī, Sharh Fuṣūs al-Hikam, 4.

6 Seyyid Muhsin 'Āmilī (Born 1905 in Iran) was one of Shī'ah Scholars, whose important book is $A$ ' yān al-Shì'ah in 55 volumes, which is an Encyclopedia of famous Sh'ite men as explanation of Imamiyyah Teaching (See: Haytham Amin, Sìrah al-Seyyid Muḥsin al-Amīn (Qum: Dār al-Najm al-Jadīd, 2000).

7 'Abbas Qumī known as Muhaddith Qumī was born in 1915 in Qum/ Iran. His famous work is Mafätih al-Jinān, which is a collection of Imamiyyah Hadīth about praying. See Shireen Mahdavi, For God, Mammon and Country: a 
There are three other great masters, who possess the same name as 'Abd al-Razzāq, which may be confused with Kāshānī. First, Abū Faḍl Kāmāl al-Dīn Abd al-Razzāq Ibn Aḥmad, one of his contemporary Sufi, who was known as Ibn al-Fūwațī al-

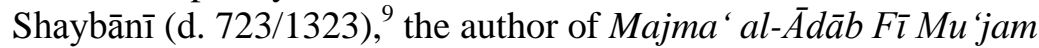
$a l-A l q a \bar{a} b$. The second is Kāmāl al-Dīn Abd al-Razzāq Ibn Isḥāq Samarqandī (d. 887/1482), ${ }^{10}$ the author of Matla' Sa'din wa Majma' Baḥrayn. The third one is 'Izz al-Dīn Maḥmūd Kāshānī (d. 735/1335), the author of Mișbāh al-Hidāyah wa Miftāh alKifāyah and Kashf al-Wujūh al-Ghar lì Ma 'ānī Nażm al-Dur.

The beginning of the second half of the fourtheen century, when Kāshānī started his education, was synchronized with the Mongol's reign. Before then, Persia, Iraq, Syria and Asia Minor were the home of culture and education. There were hundreds of schools in Hirārt, Nayshābūr, Ișfahān, Bașrah and Baghdād, but after the Mongol's devastation, these centers were completely destroyed. Most masters and students were killed or forced to leave these centers. And, even if some of them remained, they lost their previous glory and importance. ${ }^{11}$ Therefore, Kāshānī spent his entire life in insecure times, with ravaging of Chinggis relatives. It was in this period that Kāshānī studied the traditional religious science. Unfortunately, we do not have much information about him in this period, but according to his letter to 'Alā' al-

Nineteenth Century Persian Merchant, Hāj Muḥammad Ḥassan Amīn al-Zarb (N.pl.: Westview Press, 1999), 259.

8 Al-Qayșarī, Sharh Fuṣūs al-Hikam, 4; Abd al-Razzāq Kāshānī, Iiștilahạat alSüfiyyah (Cairo: Dār al-Ma'ārif, 1984), 31-32.

9 Muhammad ibn Shākir, Fawāt al-Wafìyāt (Beirut: Dār-e Șār, 1974), 1:272; Shihāb al-Dīn Abī al-Falāh, Shadahrāt al-Dhahab fì Akhbār Man Dhahab (Beirut: Dār Ibn kathīr, 1986), 6:60; Khayr al-Dīn Zereklī, al-'Alām (Beirut: Dār al-'Ilm lil Malāyīn, 1986), 3:349; Āmilī, Muḥsin Amīn, A'yān al-Shī'ah (Beirut: Dār al-Ta‘ārruf lil Mațbū'āt, 1983), 8:5.

${ }^{10} \mathrm{He}$ is the author of Mațla' Sa'dìn wa Majma 'Bahrayn, an important historical source about the Mongol and Taymurid's period. There are three valid prescriptions available in library of Iran and Turky. See 'Abd al-Husayn Zarrin Kūb, Dunbālah-ī Justijū-iy Dār Taṣawwuf Iran (Tehran: Amir kabir, 2000), 49.

11 'Ațā Mulk Ibn Muhammad Jūwaynī, Tārīkh-e Jahāngushā (Tehran: Ferdaws, 2007), 1:139; Muḥammd Qāsim Hindūshāh Istarābādī, Tarīkh-e Fereshteh (Tehran: Anjuman Āthār wa Mafākhir Farhangī, 2010), 121; George Saliba, Islamic Science and Making of the European Renaissance (USA: MIT Press, 2007), 236-243. 
Dawlah Simnānī, we can assume that he would have been an expertise in jurisprudence (Fiqh), Hadìth, Qurān interpretation (Tafsir $r$, Theology, Knowledge of Courtesy and Wisdom ${ }^{12}$. His AlSawānih al-Ghaybiyyah is proof of his proficiency in 'Arabīc literature. In addition, his treatise Mabda' wa Ma'ād is a bare sample of his widespread knowledge of Hadith. Hence, his deciple, Dāwūd al-Qayṣarī called him "Master of Scholars" and Haydar Āmulī (d. after 782/1380) ${ }^{13}$ described him as "The Greatest Master and Sea of Middling (al-Mūlì al-'Azam wa alBahr al-Khadm) also positioning him at the level of Imām Fakhr Rāzī (d. 606/1209), ${ }^{14}$ Khawjah Nāṣir al-Dīn Ṭūsī (d. 672/1273), ${ }^{15}$ al-Ghazālī (d. 505/1111) and Avicenna (d. 428/1037). ${ }^{16}$ According to Jāmī, he is the one, who possesses both inward and outward knowledge. $^{17}$

According to Kāshānī’s notes, some of the Sufi masters played important roles in his life: Sharaf al-Dīn Ibrāhīm Ibn Șadr al-Dīn Rūzbahān (d. 685/1286), Nūr al-Dīn 'Abd al-Raḥmān Isfarāyen̄i (d. ca. 698/1299) and Nūr al-Dīn 'Abd al-Ṣamad Ibn 'Alī Iṣfahānī Naṭanzī (d. 699/1300) and Shams al-Dīn Muhammad Ibn Aḥmad al-Hakim Kīshī (d. 694/1295). ${ }^{18}$

12 See Kāshān̄̄'s first letter to 'Alā' al-Dawlah Simnān̄i in Majid Hādizādeh, Majmū'ah Rasā'il (Tehran: Mirāth Maktūb, 2000).

${ }^{13} \mathrm{He}$ was the Persian jurist and Sufi, who was follower of Kubrawiyyah Order. He tried to establish that Shi'ism and genuine Sufim come from the same source and basic origin. See Sufism, an Entry to Encyclopaedia of the World of Islam, ed. Ghulām 'Ali Haddād 'Ādil, Muḥammad Jafar and Rād Tāro (UK: EWI Press, 2012), 55.

14 Abū 'Abd Allāh Muhammad Ibn 'Umar Ibn Husayn Ibn Hasan Ibn Alī Tabaristān̄i Rāzī, was a well-known Persian Sunni Muslim, theologian and philosopher. He also wrote on medicines, physics, astrology, literature, history and law. See N. Hanif, Biographical Encyclopaedia of Sufis: Central Asia and Middle East (New Delhi: Sarup \& Sons, 2002), 2:372).

${ }^{15}$ Khawjah Muḥammad Ibn Muḥammad Ibn Hasan Ṭūsī better known as Nāṣir al-Dīn al-Ṭūsī was a Persian polymath and prolific writer, an astronomer, biologist, chemist, mathematician, philosopher, physician, physicist, scientist, theologian. The Muslim scholar Ibn Khaldun (1332-1406) considered him to be the greatest of the later Persian scholars. See: The Cambridge History of Iran, ed. J. A. Boyle ( $4^{\text {th }}$ ed., Cambridge UK: University press, n.d.), 5:620.

${ }^{16}$ Haydar Āmūlī, Jami' al-Asrār wa Manba' al- Anwār (Tehran: Hermes, 2008), 498.

${ }^{17}$ Nūr al-Dīn 'Abd al-Raḥmān Jāmī, Nafaḥāt al-Uns min Haḍarāt al-Quds (Tehran: Sa'dīi, 1988), 482.

${ }^{18}$ Pierre Lory, Les Commentoires esoteriques du Quran, 234. 
The most life of Kāshānī spends to join acompny Nūr al-Dīn 'Abd al-Șamad Națanzī and Shams al-Dīn Kishī instead of traveling. He himself was an experienced master of lots of students and taught the mysterious text like Fușūs al-Hikam. One of his prominent students, Dāwud Qayșarī (d. 751/1350) reportet:

"As I joined to my master, al-Qāsān̄i, a group of my brothers was learning about the mysterious knowledge about the beauty (al-Jamāl) and glory (al-Jala $\bar{l})$ of God through reading Fușū al-Hikam by him.,"

Al-Qayșarīi, whose commentary on Fușūs al-Hikam ${ }^{20}$ is the most widely read commentary in the eastern land of Islam, ${ }^{21}$ undoubtedly, learned Fusūs by Kāshānī. ${ }^{22}$

Kāshānī at the late of his life had a journey to Sulțānyyah, where he decided to contact A'lā al-Dawlah Simnānī (d. 736/1336). According to Jāmī, Mir Iqbāl Sistān̄ accompanied Kāshānī in this journey and their discussion about the Wahdah alWujū gave him the idea to write a letter to Simnānī. ${ }^{23}$ Their correspondences is related to the one of challenging and interesting debate about the conception of Tawhid, according to theory of Ibn Arabī's teaching, called Wahdah al-Wujūd. These two letters are the representative of two different Schools of thought called Wahdah al-Wujüd and Wahdah al-Shuhüd, while they are based on the same principle Unity (Wahdah). Kāshānī wrote these letters as he was setteled in kāshan. ${ }^{24}$ Later, he decided to go to Natanz, where the journey of his education was started and his first master was rested in his tomb. That was the place, where he found his way for the first and rest for ever.

\footnotetext{
${ }^{19}$ Al-Qaysarī, Sharḥ Fușūs al-Hikam, 4.

${ }^{20}$ The important of his commentary is that the later Persian commentaries on Fusūs are based on his 'Arabīc commentary. See Massood Alī Khan and Azhar Iqbāl, Encyclopaedia of Islam (N.pl.: Commonwealth Publisher, 2005), 274; Sankar Yadav and B. N. Mandal, Global Encyclopedia of Education (New Delhi: Global ublishsing House, 2007), 1:119)

${ }^{21}$ Seyyed Hossein Nașr, History of Islam ( N.pl.: routledge, 1996), 518.

${ }^{22}$ William C. Chittik, A Short Introduction to Sufism (N.pl.: Oneworld Publications, 2000).

${ }^{23}$ Nūr al-Dīn 'Abd al-Raḥmān Jāmī, Nafaḥāt al-Uns min Haḍarāt al-Quds, 482; 'Alā al-Dawlah Simnānī, al- 'Urwah lī Ahl al-Khalwah wa al-Jilwah (Tehran: Mawlā, 1984), 46.

24 'Alā al-Dawlah Simnānī, al- 'Urwah lī Ahl al-Khalwah wa al-Jilwah 488.
} 


\section{Kāshānī on the State of al-Karīm and $a l-Q \bar{a} d \bar{i} r$}

The prominent trait of Kāshānī, is his courtesy to his masters and his effort to exonerate some of his contemporary scholars from blasphemous accusations. In addition, his tolerant and gentle approach toward his opponents shows his high spiritual stage in the spiritual path. This characteristic earned him the tendency and cooperation of minister, Khawjah Ghiyāth al-Dīn Muhammad (d. $736 / 1336),{ }^{25}$ which depicts his respectful place and influence in Mongol goverment. ${ }^{26}$

He clearly speaks about two spiritual stages, which he attained during his life: al-Karìm and al- Qādìr. As he explained about "al- 'Ibādah" in Lațāif al- A'lām fì Ishārāt ahl al-Ilhām, when the term slave ('Abd) is added to one of God's attributions. It means that this attribution is completely manifested in the slave. ${ }^{27}$ According to Kāshān̄̄' point of view, 'Abd Allāh is a slave of God, who manifested the name 'Abd, in other words, he is an image of all God's names and attributes, because he attained the ultimate stage of illumination, which is the most complete expression of God's attributes. Hence, he has the high rank among creatures and serves God in the complete form of slavery. This stage, certainly, belongs to Prophet Mohammad (p.b.u.h). ${ }^{28}$

However, Kāshānī was able to manifest two names of God: al- Karìm and al-Qādìr. Al-Karìm is one of God's names. Arabs call a person Karim, who forgives the guilty and is kind to misbehavers. ${ }^{29}$ According to Kāshānī, al-Karīm is a stage, in which God purifies the believer from all moral failure and gifted him ethical adornment. He is aware of God as generous and merciful and hopes for God's forgiveness. In his eyes, people's sins are worthless against the forgiveness of God. Moreover; he is aware of his stage and does not exceed his limit. He knows that the original owner is God and everything he has is a gift from Him;

\footnotetext{
${ }^{25}$ The minister of Abū Said Ilkhān Mongol (1317-1336)

${ }^{26}$ Kamāl al-Dīn 'Abd al-Razzāq Kāshānī, Sharh Manāzil al-Sāerīn (Beirut: Dār al-Mujtaba lil Nashr wa al-Tawzi', 1995), 2.

${ }^{27}$ Kāshān̄i, Iștilāhạat al- Șūfiyyah, ed. 'Abd al-‘āl Sharīf (Cairo: Dār al-Manār, 1992), 124

${ }^{28}$ Kāshānī, Iștịlāhāt al- Șūfiyyah, 126.

${ }^{29}$ Simnānī, Rawh al-Arwāh fi Sharh Asmā' al-Mulk al-Fattāh (N.pl.: n.pb., n.d.), 367.
} 
hence, he shares his assets with other people and forgives their failures. ${ }^{30} \mathrm{He}$ wrote:

"The whole matter is that I am your slave, The slave of a generous would never be mistreated,

It is true that I committed many sins,

But forgiveness is a custom of generous" 31

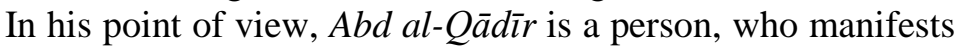
the name al-Qādìr. He observes God's mighty anywhere and God's power is beyond others. Therefore he argued:

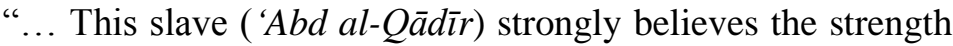
of God's assistance to creations; therefore, he finds the mortality of himself and the humility and worthless of stage of believers; as he saw the power of God existing in everything, he finds himself more needful than the slightest person". 32

$\mathrm{He}$ is aware that the entire mighty belong to God and His might covers all of creation. All actions and reactions are the manifestation of His mighty and nothing is beyond it; therefore, he portrayed God's power that nothing can be a barrier to Him from doing the right thing. On the other hand, he finds himself a humble and needful person and subsequently has understanding and tolerance towards his opponents. He wrote about the stage of alQādìr:

"I am slave to the power of Allāh,

When it appears in the action of resident,

Hence, I am characterized by humiliation and disability, Needful of the slightest being",33

According to Sufis, the supreme ethics is attainable by gaining these two stages. Kāshānī’s conduct against mistreatment of his opponents shows us the manifestation of these two ethics in his personality. For example, 'Alā al-Dawlah Simnānī excommunicated him and claimed that he is far of pure food and right saying; however, Kāshānī wrote him:

\footnotetext{
${ }^{30}$ Kāshānī, Iștiliāhāt al- Süfiyyah, p. 133-134.

${ }^{31}$ Kāshānī, Latạî al-A 'lām fì Ishārāt al-Ilhām (Tehran: Mirāth Maktūb, 2001), 505.

${ }^{32}$ Kāshānī, Lațāif al-A 'lām fì Ishārāt al-Ilhām, 512-513.

${ }^{33}$ Kāshānī, Lațāif al-A 'lām fì Ishārāt al-Ilhām, 512.
} 
"... To the great Shaykh of Islam, guardian of Shari'ah, whose inner is illuminated of light of faith, and peripatetic are the resident of his glory marquee and ..."

Then, politely continues:

"... After praying for you, I should confess that I, as a poor Sufi, never mentioned your name without full of curtsey ... I thought you may not agree with it and it may bother you..."

So, it is clear that he did not lose his courtesy and tolerance against his opponents; since he is aware that every action is not out of his power and might; rather, he tried to answer with respect and cover, their mistakes. In one of his treatises about a famous person, ${ }^{34}$ he wrote:

"... One of great master, a guardian of Sharì'ah, whose piety is basis of his knowledge calls one of pervious scholars as unawareness and lost, and claimed that he deserves punishment because of doing some mistakes, while he was a knowledgeable scholar ..."35

The courtesy, tolerance, acceptance and interaction according to all groups of Sufis, theologian and jurisprudence, are the prominent qualities of his character.

Study Islamic literatures from fourtheenth century onward, depict the polemical discussion around Ibn 'Arabī's legacy. It is not surprising, when Awhid al-Dīn Kirmānī (d. 635/1238) was called innovative by Suhrawardī ${ }^{36}$ or Simnānī, clearly, held no respect for Shaykh Akbar. In this regard, some Sufis took it upon themselves to protect his teaching vis-à-vis the controversial Muslim masters. In this regard, Kāshānī, as a commentator of Ibn 'Arabī's teachings, chose a different way from others. It is clear, who finds himself more needful than the slightest person, can never disrespect other masters.

\section{The Place of Kāshānī in Sufism}

Kāshān̄i, certainly, is one of most prolific writers in the history of Sufism. Although he is mostly known as a commentator, in this part we will present those characteristic features of his writings that help to explain his great influence on Sufism, especially in

\footnotetext{
${ }^{34}$ He might be Ibn 'Arabī.

${ }^{35}$ Pierre Lory, Ta'wīlāt al-Quran, Persian Translation, 229.

36 'Umar ibn Muhammad Suhrawardī, Rashaf al-Nașā'ị̆ al-Imāniyyah, 5.
} 
Persian Sufism, not only as a commentator, but also as an independent thinker.

\section{Kāshānī as a Commentator}

In the Muslim world, Kāshānī's name is knotted to Ibn 'Arabī as a commentator of his teachings. His interpretations bewildered both his Muslim and non-Muslim readers. Although, Ibn 'Arabī's works has been interpreted by some other Sufis like Qūnawī 9d. 673/1274), Tilmisānī (d. 690/1291), Jandī (d. 691/1292) and Furghānī (d. 699/1300), Kāshān̄̄'s commentaries possess a unique place among them. ${ }^{37}$ In this regard, the Persian Professor Bidārfar has a comparison study between Kāshān̄̄ and Tilmisāni commentary on Fuṣūṣ al-Hikam. ${ }^{38}$ However, Kāshānī’s commentary is not as long as Tilmesānī, but it is a comprehensive interpretation written in simple literature. Actually, Kāshān̄̄'s style of classification is the prominent point, which differ his commentaries from others. ${ }^{39}$

It is worthy of mention that, almost one century after Ibn 'Arabī, the School of Waḥdah al-Wujūd was in ultimate widespread by his disciples, and its vocabulary and related subjects were fixed. Therefore, Kāshānī could use more creative allegories and spiritual terms without religious apologies, and he tried to regularize the metaphysical theories founded by Ibn Arabī.

In addition, Kāshānī's tendency to write simple and keeping away from complex literary expression, absorbed not only academics, but also a broad band of non-specialists, who were interested in Sufism. ${ }^{40}$ Even contemporary scholars like Izutsu called Kāshān̄ the greatest figure emerging from Ibn Arabī's School. Current scholars recognize his commentary the second source after Fușuss and frequently refer to it in order to explain the Ibn Arabī’s teaching. ${ }^{41}$

${ }^{37}$ Rama Sankar Yadav and B.V. Mandal, Global Encyclopedia of Education, ed. N. K. Singh, 119.

${ }^{38}$ Kāshānī, Sharh Manāzil al-Sāerīn, 32.

${ }^{39}$ Lory, Persian Translation, 34.

${ }^{40}$ Haydar Āmūlī, Naș al-Nuṣūṣ (Tehran: Mū'assasah Mutāliāt wa Tahqiqāt Farhangī, 1992), 13; James Winston Morris, "Ibn 'Arabī and his Interpreters," Institute of Islamic Studies (Paris: n.pb., n.d.), 2-5.

${ }^{41}$ Toshihiko Izutsu, Sufism and Taoism (U.S: University of California Publ., 1983), 23. 
Kāshānī’s commentary is not limited only to Fusūṣ, his explanation on Manāzil al-Sāerīn of Khawjah Abd Allāh Anșārī (d. $481 \mathrm{H})$ is also well known to all exponents. Shaykh Haidar Āmulī (d. 787/1385) ${ }^{42}$ wrote about it:

“... And there are some commentaries on Manāzil al-Sāerīn; however, the greatest and best investigation among them belongs to great master, 'Abd al-Razzāq Kāshānī, the complete theist (Müwahhid), the king of Sufis, honor of nation, righteousness and religion." 43

Moreover, Kashanī's extraordinary accuracy of text, solutions to problems, mastery of Persian-'Arabīc literature and methods of writing; in addition to his spiritual experience, made his works unique. His teachings are, as well, taught in courses at some universities and traditional Islamic academics. Kāshānī himself said about his commentary:

"There was different version of Manāzil al-Säerīn, in which the phrases were dissimilar. In some part of it distortion and wrong phrases were clearly observed, while some other phrases were misleading; therefor, it was difficult to distinguish the right sentence from the wrong. Until with God's help, I received a correct version confirmed by Shaykh's writing in $475 \mathrm{H}$. So, I started to correct and safely interpret book; since, I felt in this way Shaykh has shown me his permission to work on his book." ${ }^{44}$

Generally, the style and method of Kāshānī's commentaries made them an extraordinarily archetypal. His explanation of theoretical Sufism, showing the individual spiritual realization, can be used as an example by beginners on the spiritual path.

\section{Kāshānī an Independent Author}

Kāshānī is a creative Sufi author making an archetype of guidance for better understanding of Sufis' idioms. Ibn al-Fuwațī expressed on his proficiency and skills of writing. ${ }^{45}$ His book, Iștilāhăt al-

${ }^{42}$ Haydar Āmūlī was a Shi'ite Sufi, philosophers and an early representative of Persian Imamite theosophy and one of the most distinguished commentators of Ibn 'Arabī, during the $14^{\text {th }}$ century.

${ }^{43}$ Haydar Āmūlī, Jāmī’ al-Asrār wa Manba' al-Anwār (2th ed., Qum: Markaz Mutāliāt wa Madārik Islamī, 2009), 326.

${ }^{44}$ Kāshān̄i, Sharh Manāzil al-Sāerīn, 622.

${ }^{45}$ Kāshān̄i, Sharḥ Manāzil al-Sāerīn, 622. 
Șüfiyyah, is a key guide for understanding the different stages of spritual path $(S u l \bar{u} k) .{ }^{46}$ It is the comprehensive and most read work in Sufism. It contains 760 Sufi's technical terms.

As it was mentioned before, Kāshānī considered the heritage of two Sufi zones in order to give a comprehensive image of Sufism. He, however, went further and analyzed Sufi's origin in his work Tuhfah al-Ikhwān fì Khașāiș al-Fityān. He found the origin of Sufism in Futūwwah (chivalry), which was initiated by Prophet Abraham. In this regard, he was more influenced by Khurāsān School; since chivalry was more considered and studied by Khurāsān's Sufis, such as Abd al-Raḥmān Sulamī and Shihāb al-Din Suhrawardī, than Sufis in Andalusia and Egypt.

On one hand, Kashānī used to be a disciple of Suhrawardiyyah School and familiar with theology and philosophy. His works, on the other hand, not only present the teaching of Ibn 'Arabī, but also reflect Suhrawardī philosophy. Although, in Kāshān̄̄'s cosmology, the trace of philosophy can be seen, yet it is different from Fārābi's and Avecina's view. For example, from Kāshānī's cosmology standpoint, the intellect agent possesses the second stage of determination, descent, or first stage, after the presence of essence, while it has the tenth stage according to Fārābī's and Avecina's point of view. ${ }^{47}$

In addition, Kāshānī’s works are providing a set of spiritual worldview in the treatise of Mabda' wa Ma 'a $d^{48}{ }^{48} \mathrm{He}$ also has a comparative analysis to basics principle of religion and Sufism in his Tashrīqāt treatise.

Another prominent feature of Kāshānī is his efforts for strengthening the scientific principle of Sufism through its approximation with Sharì'ah and Quran. His remarkable esoteric interpretation Ta'wilāt al-Qurān, is a proof of this claim. ${ }^{49}$

Kāshānī’s numerous compilations show his high grade knowledge; in addition, popularizing his writtings depicts his importance place in history of Sufism. Because of his high degree knowledge and talent to organize difficult subjects and make them

\footnotetext{
${ }^{46}$ Lory, Persian Translation, 3434.

${ }^{47}$ Lory, Persian Translation, 41.

${ }^{48}$ The Origin and Resurrection

49 Lory, Persian Translation, 6; N.K. Singh, Global Encyclopedia of Islamic Mystic and Mysticism (N.pl.: Global Vision, 2009), 1:119.
} 
understandable for all classes of people, his students asked him to write a commentary on Fușūṣ and Manāzil al-Sāerīn. ${ }^{50}$ In addition, due to extremely controversial arguments around origin $\left(m a b d a^{\prime}\right)$ and resurrection ( $\left.m a{ }^{\prime} \bar{a} d\right)$, some of his disciples and Governor asked him to write about it. ${ }^{51}$ Similarly, his al-Sawānih al-Ghaybiyyah was written in order to answer the questions of "People of Convent" (Khānqāh $){ }^{52}$ which contains his spiritual experiences. $^{53}$

Despite of this fact that Kāshānī' works reflects Ibn Arabī's teachings, we can observe some small different views, which marks him as an independent thinker. For example, according to spiritual stages, Ibn Arabī believed in a stage above the ultimate honest (Qurb). This is a stage of immanency (Qurbat), of which the pervious Sufis were not aware. He allocated chapter 161 of alFutūhât al-Makiyyah to this stage, which is a stage between truth and prophecy. ${ }^{54}$ According to 'Awärif al-Ma'ärif, the ultimate stage of spiritual stage is truth, so that even sometimes it is recognized as one of four basic principles of faith. ${ }^{55}$ Sufis, usually, accept that the last stage of spiritual journey is behind the stage of prophecy. Kāshānī, indeed, speaks about truth in details and tells about different kinds of it in Lațâif al-A ' lām.

Undoubtedly, after Ibn Arabī, Ghazālī and Sulamī, Kāshānī is one of the most influencial writers in the history of Sufism. Jamī called him a great scholar, who gathered all inner and outward knowledge in himself. ${ }^{56}$ Kāshānī's specific interpretation on School of Wahdah al-Wujūd with the back ground of Suhrawardiyyah Philosophy, including his personal spiritual experience, made him an independent Sufi author. The above

\footnotetext{
${ }^{50}$ Kāshānī, Sharh Fuṣūṣ al-Hikam, p. 3.

${ }^{51}$ Ibn al-Fūwațī al-Shayban̄i, Majma ' al-Ādāb fi Mu 'jam al-Alqāo , 4:181

52 The Muslim covenant is called Khānqāh. See Duğan Kuban, Muslim Religious Architecture: Development of Religious Architecture in Later Periods (N.pl.: Brill, 1974), 3:37.

53 Duğan Kuban, Muslim Religious Architecture: Development of Religious Architecture in Later Periods, 3:37.

${ }^{54}$ Ibn 'Arabī, al-Futuwhāt al-Makiyyah (Beirut: Dār Șār, 2010), 2:260; 'Umar ibn Muhammad Suhraward̄̄, 'Awārif al-Ma 'ārif (N.pl.: n.pb., 2010), 10.

${ }^{55}$ Sa'd al-Dīn Hamūyah, Al-Miṣbāh Fī al-Tașawwūf (Tehran: Mawlā', 1983), 94; Suhrawardī, 'Awārif al-Ma'ārif , 532.

${ }^{56}$ Jāmī, Nafahāat al-Uns min Haḍarāt al-Quds, 482.
} 
features are enough to distinguish his works from others and make them always at the center of scholars' interest.

\section{Kāshān̄̄ss Impact on Persian Sufism}

As previously mentioned, Kāshāni is one of the foremost and certainly one of the influential representatives of what may more rightfully be called School of Wahdah al-Wujūd. ${ }^{57}$ Through his commentaries and teachings this theory was promoted in the eastern Islamic world, especially in Persia. He is a central core of two main components of Sufism arising from different areas: First, is practical Sufism and spiritual rules from Khurāsān till Baghdād, which ultimately can be observed in Manāzil al-Säerīn and 'Awārif al-Ma 'ârif. Second, is creation and explanation of delicate spiritual concepts by Ibn 'Arab̄i and his disciple Qūnawī from Andalusia and Egypt untill Konya. Kāshānī’s equal understanding of these two mystics' zones and assimilation of them has given a complete image of Sufism. Kashanī's commentary on Ibn Arabī's teaching was the starting point of further development of Ibn Arabī's teaching in Persian. This later appeared in the new spiritual movement in Persian Sufism through his indirect successors, like Sayyid Haydar Āmulī (d.787/1385) and Ni'mat Allāh Walī (d. 834/1431), whose works frequently refer to Kāshānī and present the vitality and deep influence of him.

Among Shi'̄̄te Imāmiyyah, Āmulī was especially important in bringing Ibn al-'Arabī's teaching into the mainstream of Shi'̄te thought in Iran. He wrote enormous commentary on the Fușuss, called Nașs al-Nușūṣ and edified the abstract of Kāshānī's Isțilahāat al-Süfiyyah, which later was translated into Persian in detailed explanation. He investigated the meaning of the Fușuss on three levels: Naql (Qurān and Hadīth, as especial sources for Shi'īte), 'Aql (Theology and Philosopy), and Kashf (referring to his own experience) ${ }^{58}$ In Amuli point of view, the reality of Sufism and Shii'te Imāmiyyah are the same and true Shi'ite is

\footnotetext{
57 James Winston Morris, "Ibn 'Arabī and his Interpreters," Journal of the American Oriental Society 107 (1987); Part II-A originally appeared in JAOS, vol. 106 (1986); and Part I in. JAOS, vol. 106 (1986).

58 Āmūlī, Naș al-Nușūṣ, ed. Henry corbin and 'Uthmān īslmāil Yahyā (Tehran: Educational institute of France and Iran, 1969), 106-08.
} 
Sufis; therefore, he recognizes the Imāmyyah Infallible leaders (Imām) as Sufi. ${ }^{59}$

It is worthy of mention that Persian commentaries on the Fușuss are frequently based on the "Arabīc commentary of Kāshānī. He taught Fuṣūṣ to Dāwūd Qayșarī (d.751/1350), the author of dozens of works in 'Arabīc and Persian. His systematic philosophical introduction to Sharh al-Fușuss itself became the object of later Persian commentaries. An approval for it is the first Persian commentary on Fușūș, Nușūṣ al-Khușūs, written by his student Bābā Rukn-al-Din Shīrāzī (d. 769/1368). ${ }^{60}$

The poet and Sufi master, Shah Ni'mat-Allāh Walī, followed closely in the tracks of Kāshānī and Qayșarī. In addition, of over one hundred treatises on theoretical and practical Sufism, which are directly rooted in Wahda al-Wujüd School, he wrote Risālah Ta 'rīfāt, which is the Persian translation of Kāshānī's Iștilāhạt alSüfiyyah. ${ }^{61}$

In Persia, even some Sufi authors like 'Alā'-al-Dawlah Simnānī (d. 736/1336), who had a critical view to Ibn al-'Arabī's world view, credited markedly from terminology established by Kāshānī and his immediate followers. ${ }^{62}$ Sometimes Sufis did not take the criticisms of these authors too seriously. Typical are the remarks of Sayyid Ashraf Jahāngir Simnānī (d. 829/1426), ${ }^{63}$ who studied with Semnānī but sided with Kāshānī in his defense of Ibn al-'Arabī against Simnāni's criticisms. ${ }^{64}$ According to him, Simnāni had not correctly understood what Ibn al-'Arabī was saying. Kāshānī might have the main role to change Simnān̄̄'s opinion towards Ibn Arabī. However, Simnānī retracted his Idea about Ibn Arabī before his death and recognized him as "People of the

${ }^{59}$ Muḥsin al-Amin al-Āmūlī, $A$ 'yān al-Shī'ah (Beirut: Dār al-Ta'āruf lil Maṭbūāt, 1982), 6: 273.

${ }^{60}$ Rukn al-Dīn Shirāzī, Nușūs al-Khuṣūṣ fì al-Tarjumah al-Fuṣūṣ (Tehran: Rajab 'Alī Mažlūmī Publ., 1980).

${ }^{61}$ Nūr al-Dīn Shāh Ni'mat Allāh Walī, Rasāil Shāh Ni 'mat Allāh Walī (Tehran: Khānqāh Ni'mat Allāh, 1978), 3.

${ }^{62}$ Herman Landolt, "Der Briefwechsel Zwischen Kāshānī und Simnānī über Wahda al-Wujūd," Der Islam 50 (1973), 93-111.

${ }^{63}$ Sayyid Ashraf Jahāngir Simnānī was one of famouse Sufi in India and founder of Ashrafiyyah order, the suborder of Kubrawiyyah order. His important book is Lațaif Ashrafì, which is collected by his disciple Nizāam Ḥāji Yamanī.

${ }^{64}$ Hamid Maḥmūdiān, "Wah̆dah al-Shuhūd in Simnāni’s point of view," Irfān, no. $18,(1993), 187$. 
Right," but remained constant against the theory of Wahdah alWujūd. ${ }^{65}$

\section{Kāshānī's Works}

There are more than forty treatises related to Kāshānī; however, for some of them is a question if they were really written by him, such as al-Sirāj al-Wahhāj and Risālah F̄̄ Badāyah Khalq Insān and al-Nușūs. Despite of Kashānī's numerous treatises in Arabic and Persian, he generally is famous because of his commentaries on Fușūss al-Hikam and Manāzil al-Sāerīn and Iștilāhāàt alȘüfiyyah. In addition, his most read work is Ta'wìlat al-Quran, which is frequently published under the name of Ibn 'Arabī.

Ta'willat al-Quran, undoubtedly, is one of the valuable esoteric interpretations. It is in two volumes: The first volume begins with the commentary of Sürah Fätihah till end of Sürah Kahf, and the second volume contains commentaries of Sürah Maryam untill end of the Qurān. His book is published under the title of the Ibn 'Arabī's commenraty on Quran (Tafsìr Ibn 'Arab $\vec{l}) .{ }^{66}$ In this regard, the French scholar, Pierre Lorry discussed the questionable subject whether the author of Ta'wìlāt is Kāshānī or Ibn Arabī? He argued that Ta'wìlat belongs to Kāshānī; since the most available manuscripts of $T$ 'willat belong to him. ${ }^{67}$

There are many argumentation that proofs Ta'wìlāt belongd to Kāshānī. In the introduction of Iștiliḥ̂àt al-Șüfiyyah, Kāshānī mentioned to Ta'wìlāt al-Quran al-Karìm:

"...After, I have finished Sharh Manāzil al-Sāerīn and Sharh

fușūs al-Hikam and Ta'wīlāt al-Quran, I starred to write Iștilihāat al-Sūifiyyah ..."68

Kāshānī, sometimes, mentioned to his Ta'wīlāt in Sharh Fușūs al-Hikam:

"...Who wants to confirm, can ckeck with the Ta'wilät alQuran, which I worte...."69

"... Who wants to study the truth of this story and its similar tales, revise it in Ta'wīlāt, which I wrote about Quran...,"70

\footnotetext{
65 'Alā' al-Dawlah Simnān̄̄, Chihil Majlis (Tehran: Adib, 1985), 137 and 353.

${ }^{66}$ Ibn 'Arabī, Tafsir Ibn 'Arab (Beirut: Dār al-Kutub al-'Ilmiyyah, 2001).

${ }^{67}$ Lorry, Ta'wīlāt al-Quran, 65-66.

${ }^{68}$ Kāshānī, Iștilithāt al-Șüfiyyah (N.pl.: Dār al-Manār, 1992), 42.

${ }^{69}$ Kāshānī, Sharh Fuṣūṣ al-Hikam, 309.
} 
In addition in Ta'wīlàt al-Qurān, when Kāshānī explained the story about "Bilquis Throne," cited from Ibn "Arabī. ${ }^{71}$ On the other hand, in the second volume of Ta'wilat, the author by interpreting the verse thirty of Sürah al-Qașās called Nūr al-Din 'Abd al-Ṣamad Națanzī (d. 699/1300) as his Shaykh or pole. ${ }^{72}$ It is clear that Natanzī was one of the Suhrawardiyyah patriarchs and Kāshān̄̄'s master. ${ }^{73}$ Plus the proof of other great masters like Shaykh Haydar Āmulī, Jāmī and Shams al-Dīn Muhammad Ibn Hamzah Fanārī (d. 834/1431), ${ }^{74}$ we can conclude that Ta'wīlāt alQurān, without doubt, belongs to Kāshānī. Some of his most popular treatises are as follow:

\section{The Arabic Composition:}

\section{Ta 'wìlāt al-Qurān}

2. Ișțlạhāt al-Sufiyyah

3. Sharh Fuṣūs al-Hikam

4. Sharh Manāzil al-Sāerīn

5. Sharh Mawāqi' al-Nujūm wa Mațāli 'Ahillah al-Asrār wa al'Ulūm

6. Risāla fì Ta'wìl Bismi Allāh

7. Risālah 'Irfāniyyah

8. Risālah al-Asmāiyyah

9. Risālah Mu'ādiyyah

10. Risālah fi Qad̄à' wa Qadar

11. Al- Sunnat al-Sarrmadiyyah wa Ta'īn-i Miqdār Ayyām alRubübiyyah

12. Al-Sawānih al-Ghaybiyyah wa al-Mawāhib al- 'Ayniyyah

13. Tazkirah al-Fawā'id

14. Rashah al-Zulāl fì Sharh al-Alfāz al-Mutidāwilah Baina Arbāb al-Azwāq wa al-Ahwāl

15. Tuhfah al-Ikhwān Fī Khaṣāiṣ al-Fityān

${ }^{70}$ Kāshānī, Sharh Fuṣūṣ al-Hikam, 320 and 206.

${ }^{71}$ Kāshān̄i, Ta'wìlāt al-Qurān, 2:110.

${ }^{72}$ Kāshānī, Ta'wīlāt al-Qurān, 228.

${ }^{73}$ Kāshān̄i, Ta 'wìlāt al-Qurān, 37-38; Lory, Ta'wīlāt al-Quran, 66.

74 Āmulī, Jāmi' al-Asrār wa Manba' al-Anwār, 50, 498; Hamzah Fanārī, Miṣbah al-Uns Bayn al-Ma'qūl wa al-Mashhūd (Tehran: Mawlā', 1995), 279, 280, and 369; 'Abd al-Raḥām Jāmī, Naqd al-Nușūṣ Fī Sharh Naqsh al-Fuṣūṣ, (Tehran: Mu'assisah Muțāli'āt wa Taḥqiqāt Farhangī, 1991), 103; Jāmī, Nafahāat al-Uns Min Hadarāt al-Quds, 383. 
16. Fawā'id al-'Arabìyyah

17. Tafsī Āyat al-Kursī

18. Tafsīr Sūrah al-Jum 'ah

19. F̄̄ Tahqūq Haqīqah al-Dhät al-Ahadyyiah

20. Taḥqīq fì Ma 'ànī Alif wa Làm

\section{The Persian Composition}

21. Tuhfah al-Ikhwān fì Khașāiș al-Fityān (Kashānī fïrst wrote this treatise in Arabic, then according to the request of his students rewrited it into Persian).

22. Fù Bidāyat Khalq al-Insān

23. Risālah Mukhtașar Dār Mabda' wa Ma 'ād

24. Risālah Tashrīqāt

25. Risālah Dār Tafsīr Qwl al-Nabī: Three extermination and three salvation (Thalāth Muhlakāt wa Thalath Munjiyyāt)

26. Kāshānī's letter to Simanānī I

27. Kāshānī’s letter to Simanānī II

28. Harmonized Persian Compilation

29. Fawāid Farsī:

i. In the reality of gratitude

ii. On the question from the 'Alì Ibn abì Tâlib about justice and liberality

iii. On the inner heterogeneity between the God's word before and after that

\section{Bibliography}

Amin, Haytham. Sìrah al-Seyyid Muhsin al-Amìn. Qum: Dār alNajm al-Jadīd, 2000.

Āmulī, Haydar. Jami' al-Asrār wa Manba' al- Anwār. Tehran: Hermes, 2008.

Jāmī' al-Asrār wa Manba' al-Anwār. 2th ed., Qum: Markaz Mutāliāt wa Madārik Islamī, 2009.

Āmulī, Haydar. Naṣ al-Nuṣ̄ūs. Tehran: Mū'assasah Mutāliāt wa Taḥqiqāt Farhangī, 1992.

. Naș al-Nușūṣ, ed. Henry corbin and 'Uthmān

Īslmāil Yaḥyā. Tehran: Educational institute of France and Iran, 1969.

Al-Āmilī, Muhsin al-Amīn. A'yān al-Shì'ah. Beirut: Dār alTa'āruf lil Maṭūāât, 1982. 
lil Maṭbū'āt, 1983.

. A yān al-Shì'ah. Beirut: Dār al-Ta‘āruf

Al-Fanārī, Mullā Shams aldīn Muḥammad ibn Hamzah. Miṣbặ al-Uns Bayn al-Ma'qūl wa al-Mashhūd. Tehran: Mawlā', 1995.

Al-Qayșarī, Dawūd Ibn Mahmūd. Sharh Fuṣūs al-Hikam. Tehran: Elmī Farhangī, 1996.

Al-Shaybanī, Ibn al-Fūwațī. Majma' al-Ādāb fi Mu 'jam al-Alqāb, ed. Muhammad al-Kāzim. Tehran: Irshād Islāmī, 1995.

Chittik, William C. A Short Introduction to Sufism. N.pl.: Oneworld Publications, 2000.

Hādizādeh, 'Alā' al-Dawlah Simnānī in Majid, Majmū'ah Rasā'il. Tehran: Mirāth Maktūb, 2000.

Hanif, N. Biographical Encyclopaedia of Sufis: Central Asia and Middle East. New Delhi: Sarup \& Sons, 2002.

Hamūyah, Sa'd al-Dīn. al- Miṣbāḥ fì al-Tașawwūf. Tehran: Mawlā', 1983.

Ibn 'Arabī, Muḥammad ibn 'Alī ibn Muḥammad. Tafsir Ibn 'Arab. Beirut: Dār al-Kutub al-'Ilmiyyah, 2001.

Ibn 'Arabī. Muḥammad ibn 'Alī ibn Muḥammad. Al-Futūhāt alMakiyyah. Beirut: Dār Șār, 2010.

Istarābādī, Muḥammd Qāsim Hindūshāh. Tarīkh-e Fereshteh. Tehran: Anjuman Āthār wa Mafākhir Farhangī, 2010.

Izutsu, Toshihiko. Sufism and Taoism. U.S: University of California Publ., 1983

Jāmī, Nūr al-Dīn 'Abd al-Raḥmān. Nafaḥāt al-Uns min Haḍarāt al-Quds. Tehran: Sa'dī, 1988.

Jāmī, 'Abd al-Raḥām. Naqd al-Nuṣūṣ fì Sharh Naqsh al-Fuṣūṣ.

Tehran: Mu'assisah Mutạ̄i ’āt wa Taḥqiqāt Farhangī, 1991.

Kāshānī, Kamāl al-Dīn 'Abd al-Razzāq. Iiș̣ilahạat al-Șūfiyyah. Cairo: Dār al-Ma’ārif, 1984.

Tehran: Mirāth Maktūb, 2001.

Lațāif al-A'lām fì Ishārāt al-Ilhām. . Sharh Manāzil al-Sāerīn. Beirut: Dār alMujtaba lil Nashr wa al-Tawzi', 1995. . Iștilāhāt al- Șūfiyyah, ed. 'Abd al-'āl Sharîf. Cairo: Dār al-Manār, 1992.

Kāshān̄i, Khan, Massood Alī and Iqbāl Azhar. Encyclopaedia of Islam. N.pl.: Commonwealth Publisher, 2005. 
Kuban, Duğan. Muslim Religious Architecture: Development of Religious Architecture in Later Periods. N.pl.: Brill, 1974.

Landolt, Herman. "Der Briefwechsel Zwischen Kāshānī und Simnānī über Wahda al-Wujūd," Der Islam 50 (1973): 93-111.

Lory, Pierre. Les Commentoires esoteriques du Quran, trans. Zaynab Pudineh Āqāī. Tehran: Hikmat, 2004.

Maḥmūdiān, Hamid. "Waḥdah al-Shuhūd in Simnāni's point of view." Irfān, no. 18, (1993): 187.

Mahdavi, Shireen. For God, Mammon and Country: a Nineteenth Century Persian Merchant, Hāj Muhammad Hassan Amīn alZarb. N.pl.: Westview Press, 1999.

Morris, James Winston. "Ibn 'Arabī and his Interpreters," Journal of the American Oriental Society 107 (1987); Part II-A originally appeared in JAOS, vol. 106 (1986); and Part I in. JAOS, vol. 106 (1986).

Muḥammad Jūwaynī, 'Aț̣a Mulk Ibn. Tārīkh-e Jahāngushā. Tehran: Ferdaws, 2007.

Nașr, Seyyed Hossein. History of Islam. N.pl.: routledge, $1996 .$.

Shākir, Muḥammad ibn. Fawāt al-Wafìyāt. Beirut: Dār-e Șār, 1974.

Shihāb al-Dīn, Abī al-Falāḥ. Shadahrāt al-Dhahab fì Akhbār Man Dhahab. Beirut: Dār Ibn kathīr, 1986.

Sankar Yadav and B. N. Mandal, Global Encyclopedia of Education (New Delhi: Global ublishsing House, 2007.

Saliba, George. Islamic Science and Making of the European Renaissance. USA: MIT Press, 2007.

Simnānī, 'Alā al-Dawlah. Al-'Urwah lī Ahl al-Khalwah wa alJilwah. Tehran: Mawlā, 1984.

Simnānī, Rawh al-Arwāh fi Sharh Asmā' al-Mulk al-Fattāh. N.pl.: n.pb., n.d..

Singh, N.K. Global Encyclopedia of Islamic Mystic and Mysticism. N.pl.: Global Vision, 2009.

Sufism, an Entry to Encyclopaedia of the World of Islam, ed. Ghulām 'Ali Haddād 'Ādil, Muḥammad Jafar and Rād Tāro. UK: EWI Press, 2012.

Suhrawardī, 'Umar ibn Muhammad. 'Awārif al-Ma 'ārif . N.pl.: n.pb., 2010.

The Cambridge History of Iran, ed. J. A. Boyle. $4^{\text {th }}$ ed., Cambridge UK: University press, n.d.. 
Shirāzī, Rukn al-Dīn. Nuṣūṣ al-Khușūṣ fì al-Tarjumah al-Fuṣūṣ. Tehran: Rajab 'Alī Maẓlūmī Publ., 1980.

Simnānī, 'Alā' al-Dawlah. Chihil Majlis. Tehran: Adib, 1985.

Tabrizī, Mudarris. Rayhānah al-Adab. Tehran: Khayyām, 1995.

Walī, Nūr al-Dīn Shāh Ni'mat Allāh, Rasāil Shāh Ni 'mat Allāh Walī. Tehran: Khānqāh Ni'mat Allāh, 1978.

Yadav, Rama Sankar and Mandal, B.V. Global Encyclopedia of Education, ed. N. K. Singh (N.pl.: Global Vision Publishing Ho., 2007), 1:121.

Zādeh, Majīd Hādī. Majmū'at Rasā'il wa Mușannafāt. Tehran: Mirāth Maktūb, 2000.

Zarrin Kūb, 'Abd al-Ḥusayn. Dunbālah-ī Justijū-iy Dār Taṣawwuf Iran. Tehran: Amir kabir, 2000.

Zereklī, Khayr al-Dīn. Al-'Alām. Beirut: Dār al-'Ilm lil Malāyīn, 1986. 